\title{
Runoff simulation with eight different flow accumulation algorithms: \\ Recommendations using a spatially distributed and open-source model
}

\author{
M. López-Vicente ${ }^{\text {a, }}$, C. Pérez-Bielsa ${ }^{\text {b }}$, T. López-Montero a , L.J. Lambán b ${ }^{\text {, and A. Navas a }}$ \\ ${ }^{a}$ Department of Soil and Water, Estación Experimental de Aula Dei (EEAD-CSIC), Avda. Montañana 1005, 50059 - Zaragoza, Spain \\ ${ }^{b}$ Instituto Geológico y Minero de España (IGME), Unidad de Zaragoza, C/ Manuel Lasala 44, 50006 - Zaragoza, Spain

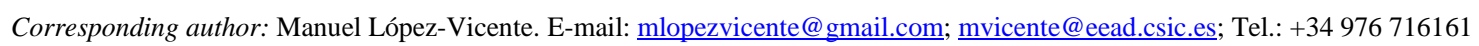

Article history: Received 16 July 2014; Accepted 14 August 2014; Published 7 September 2014

http://dx.doi.org/10.1016/j.envsoft.2014.08.025

ELSEVIER: Environmental Modelling \& Software 62 (2014) 11-21

\begin{abstract}
Flow accumulation algorithms (FAAs) predict the cumulative upstream drainage but each FAA generates a different map and this uncertainty still remains unsolved. This study makes advances in flow path research by testing 8 FAAs and analyzing the uncertainties of 15 simulations. The $D R 2-2013^{\odot} S A G A v 1.0$ hydrological software is presented in a study carried out for two catchment lakes (NE Spain) over a 69-month test period. The best simulations were obtained with two single flow (Rho8 and Deterministic Infinity) and two multiple flow (Multiple Flow with threshold value and Triangular Multiple Flow) algorithms. Correlations between runoff depths and lake levels improved when the test period was split into wet and dry seasons. Correlations also improved with a one-month delay in response time and no delay in the large and small lakes. The $D R 2-2013^{\odot}$ tool helped predict changes in lake volume and the highest model efficiencies were obtained with the multiple flow algorithms.
\end{abstract}

Keywords: DR2 model; SAGA GIS; flow accumulation algorithm; runoff; lake water level monitoring; Estaña Lakes 


\section{Introduction}

One of the unsolved issues in runoff modelling studies is the choice of the right flow accumulation algorithm (FAA) for different locations, variations in rainfall characteristics and spatial and temporal scales. Land topography impacts hydrological, geomorphological and ecological processes that are active on a landscape [Tesfa et al., 2011], while the distribution of gentle slopes and steep areas, the presence or absence of gullies, streams, sinks and flat areas as well as the occurrence of abrupt changes in slope steepness, natural or man-made (e.g. infrastructures), lead to the concentration and dispersion of runoff and making quantification and prediction a complex task [Choi, 2012]. The different FAAs enrich the information that is available from digital elevation models (DEMs) by providing a structured representation of overland flow that serves as a basis for calculating runoff and other flow related quantities [Tarboton and Baker, 2008]. However, each of the available FAAs, ca. 10 in the literature of runoff studies, generates different output maps in the same area and using the same climatic and physiographic inputs [López-Vicente and Navas, 2010; Pilesjö and Hasan, 2014]. DEM resolution and the choice of the processing algorithm cause uncertainties in most hydrological and soil erosion models [Liu et al., 2011].

There are two main types of FAAs: single flow and multiple flow direction algorithms (Fig. 1). The Deterministic eight-node, $D 8$ [O'Callaghan and Mark, 1984], single flow direction model uses the direction of steepest descent toward one of the eight neighboring grid cells to represent the flow field. As there is no option for the flow to be distributed to two cells, it tends to concentrate along distinct, often artificially straight lines. A further problem is that the steepest gradient actually might fall between two of the eight cardinal and diagonal directions [Seibert and McGlynn, 2007]. The quasi-random eight-nodealgorithm, Rho8 [Fairfield and Leymarie, 1991], is a stochastic version of the $D 8$ algorithm in which a degree of randomness is introduced into the 
flow direction computations in order to break up parallel flow paths and provide an expected flow direction equal to the aspect. As in the case of the $D 8$ algorithm, the Rho 8 algorithm cannot model flow dispersion, but it does simulate more realistic-looking flow networks. The breakup of long parallel flow paths produces many more cells without an upslope connection, distorting the distribution of the contributing area. The randomizing of flow directions also results in different flow networks each time the algorithm is run [Gallant and Wilson, 1996].

In the Kinematic Routing Algorithm, KRA [Lea, 1992], the flow is compared to a rolling ball moving in the direction of the steepest slope on a plane surface. The flow accumulation for a given cell is calculated as the number of flow paths passing through that cell multiplied by the grid cell area. The two Directional Block-Centered Routing 2D-Jensen algorithm [Jensen, 1996] provides a range of bifurcation to one division into two cells. In an attempt to overcome the limitation of only eight possible directions, Tarboton [1997] suggested using triangular facets. Tarboton termed this approach Deterministic Infinity, $D \infty$ or DInf, to describe infinite possible single direction flow pathways. The DInf approach represents flow direction as a vector along the direction of steepest downward slope on the eight triangular facets centered at each grid cell. Flow from a grid cell is shared between the two downslope grid cells closest to the vector flow angle, based on angle proportioning.

Multiple flow direction methods proportionally allocate the outflow from each grid cell to one or more downslope grid cells. The Multiple Flow Direction algorithm, MFD, distributes the flow to all the neighboring downslope cells weighted according to slope [Freeman, 1991 and Quinn et al., 1991] and tends to produce more realistic-looking spatial patterns than the $D 8$ algorithm. The disadvantage of the MFD algorithm is that the area from one cell is routed to all downslope cells and thus is dispersed to a large degree even for convergent hillslopes. In the Braunschweiger Digitales Reliefmodell, BDR algorithm [Bauer et al., 1985] the flow is split between the cell whose orientation is nearest to the aspect of the center cell and its two adjacent cells. In the 
stream tube-based Digital Elevation Model Networks, DEMON algorithm [Costa-Cabral and Burges, 1994], a drop of water placed randomly in any cell will flow across that cell in the direction dictated by the cell's aspect until it reaches the edge of the cell and enters an adjacent cell, at which point it begins to flow in the direction determined by the new cell. Channel flow occurs when two adjacent cells flow toward their common boundary and the flow then follows that boundary [Brown et al., 2003]. This algorithm has theoretical advantages but is too complex and case-specific to be implemented for most applications. To reduce dispersion Seibert and McGlynn [2007] developed the Triangular Multiple Flow Direction algorithm, TMFD, which avoids unrealistic dispersion on planar or concave hillslopes while allowing multiple flow directions on convex hillslopes.

Geographic information systems (GIS) allow the use of FAAs to be extended to other disciplines such as the assessment of dam trapping-efficiencies [Schäuble et al., 2008], the movement of pollutants [White et al., 2010] or the effect of stormwater infrastructures [Choi, 2012]. Hydrologic simulation has advanced rapidly and computerized frameworks such as the HEC-HMS, MODFLOW and MIKE-SHE models have become essential tools for understanding human influences on river flows and designing ecologically sustainable approaches [Halwatura and Najim, 2013].

Accurate simulation of runoff values and patterns is critical in order to obtain reliable predictions using surface hydrology and soil erosion models. To date, a moderate number of studies have analyzed surface flow paths using different FAAs [e.g. Wolock and McCabe Jr, 1995; Clarke and Lee, 2007 and Rampi et al., 2014] but very few of them have assessed the spatial congruence between predicted runoff using different FAAs and the actual patterns and values [Endreny and Wood, 2003; Huang et al., 2007]. To the best of our knowledge there have been no runoff production studies carried out using FAAs within the context of oscillations in 
lake levels and water volumes. Prediction uncertainty is a matter yet to be resolved and thus contributions aimed at solving this controversial issue are required.

In this study we evaluate the uncertainties of fifteen runoff predictions, depths and spatial patterns, obtained with eight FAAs, four of which are single flow and four multiple flow, with and without threshold values for linear flow. To achieve this objective we firstly present the $D R 2$ $2013^{\odot}$ SAGA v1.0 software (from now on $D R 2-2013^{\odot}$ tool), which is the first programmed (as yet unpublished) and extended version of the DR2-2013 (Distributed Rainfall-Runoff) model [LópezVicente et al., 2014]. The module is developed for open-source SAGA ${ }^{\odot} 2.0 .8$ GIS software. The $D R 2-2013^{\odot}$ tool is run in the watersheds of two freshwater lakes located in the Spanish Pyrenees to analyze runoff predictions in relation to the measured variations in the water level of the lakes over a 69-month test period. The uncertainties of each prediction are discussed in order to select the most appropriate FAAs. Finally, we assess the predictive power of the $D R 2-2013^{\odot}$ tool to estimate the water volume of a lake at monthly scale and its interest for predicting predominant processes of rises and falls in water levels. This article provides a new contribution to the studies of flow paths with different FAAs and fills a gap in the literature of runoff simulation in wetlands with different FAAs. The results will also be of interest for further studies on water balance at catchment scale to achieve accurate estimations of runoff depths and patterns.

\section{Materials and methods}

\subsection{The open source $D R 2-2013^{\oplus} S A G A$ v1.0 water balance model}

\subsubsection{Software development}

The GIS-based water balance DR2-2013 model [López-Vicente et al., 2014] is the third version of the DR2 (Distributed Rainfall-Runoff) hydrological model [López-Vicente and Navas, 2012]. It computes the depth of water stored and infiltrated in the soil and the runoff depth, considering spatial and temporal variations in rainfall intensity, soil saturation and upslope 
contributing factors. This model also provides the basis for the hydrological module of the $\underline{\text { Soil }}$ Erosion and Redistribution Tool (SERT) model [López-Vicente et al., 2013]. In order to extend the use of the DR2-2013 model, a module for the open-source, free SAGA ${ }^{\circledR} 2.0 .8$ (for 32 bit Windows) GIS software has been developed, called $D R 2-2013^{\odot} S A G A$ v1.0. A beta version with only one FAA, the MFD, was firstly presented [López-Montero et al., 2013] and since October 2013 the executable file (DR2.dll) of the complete version is available for free downloading (http://digital.csic.es/handle/10261/84613). The $D R 2-2013^{\odot}$ tool is presented in a user-friendly interface with the aim of engaging the interest of the scientific and academic community. The

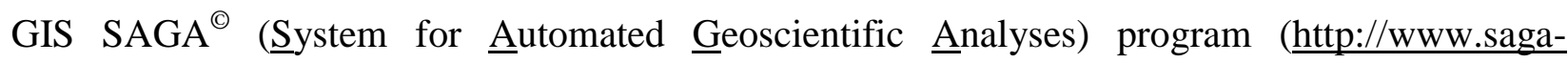
gis.org/en/index.html) supports vector and, especially, raster data. The Application Programming Interface (API) provides data object models and basic definitions for programming scientific modules and module libraries are developed using $\mathrm{C}++$ code. The script of the module is summarized in 7612 lines in two files (DR2.cpp and DR2.h) that are compiled in one file (DR2.dll). The four single flow (D8, Rho8, KRA and DInf) and the four multiple flow (MFD, BDR, DEMON and TMFD) FAAs provided in SAGA ${ }^{\odot} 2.0 .8$ were included in the "Catchment Area Options" window of the module and were run with and without considering threshold values of potential cumulative runoff for the beginning of linear flow lines. Commercial GIS software (for example, IDRISI, ArcGIS, GRASS, PCRaster) and tools (TauDEM v5.x, HydroTools v1.0, AccumPlus v1.0) and most downloaded hydrological and soil erosion models, such as SWAT (http://swat.tamu.edu/software/arcswat/) and WaTEM/SEDEM (http://geo.kuleuven.be/geography/modelling/) are commonly run with two or three FAAs, usually the $D 8, D I n f$ and $M F D$ algorithms. The $D R 2-2013^{\odot}$ tool can generate fifteen different spatial patterns of runoff and thus offers users a novel tool for runoff studies.

\subsubsection{Runoff simulation}


Effective cumulative runoff $\left(C Q_{e f f}, \mathrm{~mm}\right)$ is calculated following a three-step procedure. In the first step, the time to ponding, $T p$ (s), and the unsaturated cells and cells saturated by direct rainfall (no runoff contribution) are differentiated:

$$
\begin{aligned}
& \frac{1}{2} \frac{S p_{i m}^{2}}{K_{f s}} \ln \left(\frac{I_{m}}{I_{m}-K_{f s}}\right) \leq T p_{i m} \leq \frac{1}{2} \frac{S p_{i m}^{2}}{I_{m}-K_{f s}} \\
& S p_{i m}=\sqrt{2 \cdot ₫ \theta_{i m} \Phi_{i}} \\
& \Delta \theta_{i m}=\theta_{\text {Seff-i }}-\theta_{0-i m}
\end{aligned}
$$

where $S p$ is the soil sorptivity $\left(\mathrm{cm} \mathrm{s}^{-0.5}\right), K_{f s}$ is the saturated hydraulic conductivity of the topsoil $\left(\mathrm{cm} \mathrm{s}^{-1}\right), I\left(\mathrm{~cm} \mathrm{~s}^{-1}\right)$ is the average rainfall intensity, $\phi$ is the matrix flux potential $\left(\mathrm{cm}^{2} \mathrm{~s}^{-1}\right)$ of each soil type, and $\theta_{\text {Seff }}\left(\%\right.$ vol.) and $\theta_{0}(\%$ vol. $)$ are the effective saturated and initial or antecedent volumetric water content of the soil, respectively. The subscripts $i$ and $m$ correspond to each raster cell and to each month of the year, respectively. Once topsoil is saturated the initial runoff per raster cell, $Q_{0}(\mathrm{~mm})$, is estimated as a function of the depths of effective rainfall, $E R$ $(\mathrm{mm})$, rainfall to ponding, $R p(\mathrm{~mm})$, and the average number of rainfall events, $e(\mathrm{n})$ :

$$
\begin{aligned}
& \left.Q_{0 i m}=E R_{i m}-R p_{i m} e_{m}=E R_{i m}-\boldsymbol{\top} p_{i m} I_{m} e_{m}\right] 0 \\
& E R_{i m}=R_{m} \varangle-A_{i m} Z \cos S_{i}
\end{aligned}
$$

where $A(0-1)$ is the depth of precipitation intercepted by the canopy in relation to the total rainfall depth, $R(\mathrm{~mm})$, and $S$ (radians) is the slope angle. Once $T p$ and $Q_{0}$ have been calculated at each measurement point, the corresponding maps are created with the Kriging interpolation method (ordinary type with constant trend removal) that obtains the minimum standard error.

In the second step, $Q_{0}$, is routed into the DEM using one of the selected FAA, $F A A_{X-T y p e}$ in Eq. (6), and the potential cumulative runoff, $C Q_{0}(\mathrm{~mm})$, is obtained. The effect of manmade linear landscape elements (LLEs) such as trails, ditches, stone walls, and buffer strips is added as an effective modifier of the natural runoff pathways [more details in Borselli et al., 2008]. The inclusion of the LEEs raster mask improves model predictions in anthropized landscapes: 


$$
\begin{aligned}
& C Q_{0 m}=f \boldsymbol{Q}_{0 i m}, F A A_{X-T y p e}, L L E s, \mathrm{DEM}_{\mathrm{resol}}- \\
& C Q_{0 B m}=\alpha \cdot C Q_{0 m}=\frac{\sum_{i=1}^{i=k} E R_{i m}-\sum_{i=1}^{i=k} R p_{i m} e_{m}}{\sum_{i=1}^{i=k} C Q_{0 m}} \cdot C Q_{0 m}
\end{aligned}
$$

where resol subscript is the spatial resolution of the DEM, given that the runoff depth also depends on this parameter, and $\alpha$ is the water balance correction factor. A map including all LLEs was created and a raster mask with two values, 0 for the LLEs and 1 for the remaining area, was created to modify the map of flow direction used in the FAA. The effective cumulative runoff, $C Q_{e f f}(\mathrm{~mm})$, is calculated after considering the saturated hydraulic conductivity, $K_{f s}\left(\mathrm{~mm} \mathrm{~s}^{-1}\right)$, and the average duration of a storm after the soil becomes saturated until the end of the rainfall event for each month $m, T q_{m}(\mathrm{~s})$ :

$$
\begin{aligned}
& C Q_{e f f-m}=C Q_{0 B m}-K_{f s} T q_{m} e e_{m}-S S_{\text {max }-m} e e_{m} \sin S \\
& T q_{m}=\left(T E R_{m}-T p_{m}\right)+T q_{A f E R}=\left(T E R_{m}-T p_{m}\right)+F l L / F l V_{-}^{-}
\end{aligned}
$$

and the maximum amount of water retained on the soil surface, $S S_{\max }(\mathrm{mm})$ :

$$
S S_{\max -m}=0.5 R G_{m} \frac{\sin ^{2} \$ I G-S \cot \$ I G+S+\cot \$ I G-S^{-}}{\sin \$ I G}
$$

where $e e_{m}(\mathrm{n})$ is the average number of monthly rainfall erosive events, $T E R_{m}(\mathrm{~s})$ is the total duration of an average monthly storm event, $F l L(\mathrm{~m})$ is the flow length, $F l V(\mathrm{~m} / \mathrm{s})$ is the flow velocity, $R G(\mathrm{~mm})$ is the surface roughness, and $S I G$ (radians) is the surface soil and surface furrow angle. Water demand by evapotranspiration is included in the DR2 model to estimate the soil moisture status although it is not used in the quantification of $C Q_{e f f}$.

\subsection{Study area}

\subsubsection{Location, catchment, soil and climate characteristics}


The Estaña Lakes catchment (246 ha) is an endorheic complex made up of three fresh water lakes (total area of $17 \mathrm{ha}$ ) and fifteen sub-catchments with the presence of seventeen dolines [López-Vicente et al., 2009a]. It is located at the Sierras Marginales of the Central Spanish PrePyrenees and within the Ebro River Basin (Fig. 2.a). The lakes are called "Estanque de Arriba" Lake (EA from now on), "Estanque Grande de Abajo" Lake (EGA from now on) and "Estanque Pequeño de Abajo" Lake (Fig. 2.b). The EA Lake is circular in shape (200 m diameter) with a maximum depth of $7 \mathrm{~m}$ and has a 69 ha contributing area. The EGA Lake, which is $250 \mathrm{~m}$ to the southeast of the EA Lake and aligned with it, forms an uvala (a coalescence of sinkholes) with a sill in its central part that separates two depressions of about 360 and $325 \mathrm{~m}$ in diameter and maximum depths of 12 and $20 \mathrm{~m}$, respectively. The contributing area totals 109 ha and up to 15 $\mathrm{m}$ of sediments have accumulated in the deepest portion of the lake [Morellón et al., 2011]. Historical records document the existence of higher lake levels in the past [Morellón et al., 2011] and the current severe drop in the level of the EGA Lake is a cause of social and environmental concern [Macías, 2013]. Water chemical composition (e.g. $\mathrm{Ca}^{2+}, \mathrm{Mg}^{2+}, \mathrm{HCO}_{3}{ }^{1-}, \mathrm{SO}_{4}{ }^{2-}$ ) differs in the two main lakes and electrical conductivity averages ca. 1,500 and 4,000 $\mathrm{uS} \mathrm{cm}^{-1}$ in the EA and EGA Lakes [Pérez-Bielsa et al., 2008]. The third lake is very small and it is almost silted up with sediments and for this reason it was not included in this study. The three lakes and their riparian vegetation have come under regional protection since 1997 and are included in the European NATURA 2000 network as Sites of Community Importance. Land uses are those characteristic of the typical Mediterranean rain-fed agro-ecosystem where natural and anthropogenic areas are heterogeneously distributed. Winter cereal crops account for $28 \%$ of the total surface area whereas natural vegetation includes Mediterranean forest (40\%) and scrublands $(15 \%)$ (Fig 2.c).

Six types of soils are distinguished using the FAO classification [López-Vicente and Navas, 2012]: Calcisols (accounting for 32\% of the total surface area, which is mainly cultivated), 
Leptosols (32\%, with forest cover), Regosols (23\%), Gypsisols (5\%), Gleysols (4\%) and Vertisols (3\%). Gleysols appear around the lakes where the water table is seasonally near the soil surface. Soil types present a complex spatial distribution and the values of saturated hydraulic conductivity of the topsoil (from 5.9 to $433.8 \mathrm{~mm} \mathrm{day}^{-1}$ ) and matrix flux potential (0.0002 to $0.0401 \mathrm{~cm}^{2} \mathrm{~s}^{-1}$ ) vary significantly [López-Vicente et al., 2013]. Texture is mainly silty loam and in some parts sandy loam, loam and silty clay. Elevation ranges between 676 and $896 \mathrm{~m}$ a.s.l. and slope steepness mean is $19.5 \%$ with gentle slopes $(\mathrm{S}>8 \%)$ occupying $33 \%$ of the study area.

The climate is continental Mediterranean with two rainy periods, in spring and fall, and a dry summer with thunderstorms. At the Canelles weather station (Ebro Water Authorities, CHE), located $8 \mathrm{~km}$ to the southeast of the study area, the average precipitation was $520 \mathrm{~mm}$ for the reference period 1961-1990 (World Meteorological Organization) whereas the average precipitation for the last twenty years (1994-2013) was 12\% less (457 mm) (Fig. 3.a). Average annual evapotranspiration is $1216 \mathrm{~mm}$ (Fig. 3.a) and annual precipitation has a strong interannual oscillation. The wet season, from October till March, is defined as the period with the highest ratio between total rainfall depth $(E R)$ and potential evapotranspiration $\left(E T_{0}\right)$. The dry season, from April till September, presents the lowest ratio between $E R$ and $E T_{0}$. Out of an average number of 83 annual rainfall events only 11 are considered as erosive events, ee in Eq. (8) [see definition in Renard et al., 1991], with a rainfall amount $>12.7 \mathrm{~mm}$ or a peak rainfall intensity $>6.35 \mathrm{~mm}$ in $15 \mathrm{~min}$. Low summer precipitation and long periods of low rainfall depth reduces the volume of water stored in the soils and lakes.

\subsubsection{Hydrogeological functioning and runoff production}

The hydrogeological functioning of the catchment is related to its geological structure and geomorphological history [López-Vicente et al., 2009a] with karstification of the Triassic materials. The main aquifer in contact with the Estaña Lakes corresponds to carbonates 
(Muschelkalk facies) characterized by secondary porosity due to fracturing and karstification [Pérez-Bielsa et al., 2012]. The lutites, clays and evaporates (Middle-Muschelkalk and Keüper facies) have been identified as the aquitards. The local aquifer is approximately coincident with the surface basin and is disconnected with respect to the regional aquifers (carbonates of the Estopiñán Syncline). The aquifer is shallow near the lakes and increases in depth (not thickness) the further the distance from them, displaying a preferential NW-SE flow with entry of water in the north-west area [Pérez-Bielsa and Lambán, 2009]. Transmissivity is high (between 400 and $1600 \mathrm{~m}^{2}$ day $^{-1}$ ) and shows relatively short transit times with a rapid response to precipitation [Pérez-Bielsa, 2013].

Moderate karst processes explain the abundance of depressions, sinks and gullies where runoff can be concentrated. Although 16 gully systems appear in the hillslopes, none of them reach the lakes due to the presence of flat-bottom valleys surrounding the lakes and anthropogenic control of runoff connectivity by the LLEs (Fig 2.b). Gully discharges vary strongly over time and space, from long periods without any runoff production, to short periods, at an hourly and daily scale, where runoff depths reach high values and can even affect the lowlands. When runoff appears at the bottom of the catchment it is spread over the crops that surround the lakes and no stream or overland flow pathway can be distinguished before reaching the lake shores. Previous studies revealed a marked variability of the topsoil moisture content in this area throughout the seasons and also for different physiographic conditions [López-Vicente et al., 2009b].

\subsection{Input acquisition and model parameterization}

\subsubsection{Lake monitoring}

Water level monitoring of both lakes was performed with two OTT ${ }^{\odot}$ Hydrometry Mini Orpheus pressure sensors [Pérez-Bielsa, 2013] (Fig. 3.b). Each sensor was placed several meters below the surface and was immobilized by means of a polyethylene pipeline connected to the 
surface through a steel pipe anchored to the ground with a concrete base. After these operations the unit simulated a conventional piezometer. The pressure sensor was chosen for its accuracy $( \pm$ $1 \mathrm{~mm})$, small size $(22 \mathrm{~mm})$ and supply autonomy and measurement frequency was hourly. In order to convert the water levels to absolute high (meters above sea level; $\mathrm{m}$ a.s.1.), a georeferencing campaign was carried out on August $6^{\text {th }} 2009$ using the trigonometric station of San Quílez as the base [Pérez-Bielsa, 2013]. The equipment employed was an Ashtech ProMark $^{T M} 3$, with centimeter accuracy. At the time of the survey water surface elevation was 673.52 $\mathrm{m}$ a.s.1. in the EGA Lake and $678.97 \mathrm{~m}$ a.s.1. in the EA Lake. Total measurements of the water levels were recorded from August 2007 to April 2013 (69 months). The EA Lake sensor was damaged in August 2012 and available data end at this date.

The different response of the EGA Lake, with a clear drop in its water level in the later years, compared to the EA Lake, with similar water level values, can be mainly explained by the different transmissivity values between the local aquifer and each lake and by the role played by the clays and gypsum, which act as an aquitard with a very low transmissivity Pérez-Bielsa [2013]. In a minor way, the different behaviors of both lakes is explained by the recent mismanagement of the ditch that connects both lakes. In the past this ditch allowed a moderate transfer of water from the EA Lake to the EGA Lake. The average recharge from the local aquifer to the EGA Lake, $Q_{\text {in }}\left(\mathrm{m}^{3}\right)$, and the volume of water leaving the lake to the aquifer, $Q_{\text {out }}\left(\mathrm{m}^{3}\right)$, was estimated to be ca. 270 and $128 \mathrm{~m}^{3}$ day $^{-1}$, respectively, using the chloride balance method [Eriksson and Khunakasem, 1969; Custodio and Llamas, 1983].

Lake bathymetry was obtained with the Kriging interpolation method (ordinary type with constant trend removal) and the Golden Surfer ${ }^{\circledR} 7$ software, using ca. 250 depth data distributed along the bottom lakes [Morellón et al., 2011]. Lake water volumes were then calculated with the measured water levels and the contour lines generated every $0.5 \mathrm{~m}$ of depth [more details in Pérez-Bielsa, 2013]. Since the $D R 2-2013^{\odot}$ tool requires high temporal resolution data of rainfall 
values, especially of rainfall intensity in 30 minutes $\left(I_{30}\right)$, we used the values recorded every 15 minutes at the Canelles weather station. The threshold values used in the FAAs to model linear flow lines were calculated from 12 control points located in the 16 gully systems as performed by López-Vicente and Navas [2010] (Fig. 2.b). The 16 gully systems have an average length of 220 meters; they start at an average distance of 303 meters from the divides and are not connected to each other.

\subsubsection{Field measurements}

The soil, vegetation, topographic and land use input values correspond to those obtained and measured in previous studies performed in the Estaña Lakes catchment using 236 soil samples [López-Vicente and Navas, 2012; López-Vicente et al., 2013]. A SIG value of 30 was applied, in line with the value used in the previous application of the $D R 2$ model. The roughness value, $R G$ in Eq. (10), for forest areas $(R G=20.3 \mathrm{~mm})$ was taken from Renard et al. [1991] whereas random (32 $\mathrm{mm}$ for the plough) and orientated (250 $\mathrm{mm}$ for the plough) roughness for cultivated soils were taken from Gilley and Finkner [1991]. Once the grid system (raster cell resolution, simulation extent and UTM location) was defined in the $D R 2-2013^{\odot}$ tool, all inputs were loaded as ASCII files (.asc) except the climatic values that were loaded from tables (.txt, .csv and .dbf files).

Daily rainfall values were also recorded at the Estaña weather station (IGME, Spanish Geological and Mining Institute) and the correlation between these values and those of the water level of both lakes were analyzed (Fig. 3.c). There is a gap in rainfall values between December 2011 and September 2012 and in the water levels of the EGA Lake between February 2009 and April 2009. The charts in Figure 3.c show a relatively quick response in the water level of both lakes after the episodes of intense rainfall and this short response time justifies the methodology used in this study to calculate a correlation between the values of predicted runoff production 
with the different FAAs and the measured values of water level in both lakes. This hydrological behavior is in line with other studies carried out in karst landscapes where carbonate rocks are characterized by rapid transport of surface water to groundwater [Li et al., 2011]. We assume that although shallow subsurface flows on karst terrains are not relevant during runoff events, they are so after runoff ends, in explaining the transport of subsurface water to the lakes. Previous studies have demonstrated that the physiographic characteristics of the Estaña Lakes catchment enable accurate estimation of runoff and sediment balance [López-Vicente and Navas, 2010] proving it to be a suitable site for pursuing the objectives of this study.

\section{Results and discussion}

\subsection{Spatial patterns of runoff and selection of the FAAs}

The $D R 2-2013^{\oplus}$ tool was run 291 times, 1680 output maps were generated and the total size of information was over 5 gigabytes. The first analysis was carried out on an annual basis using the 15 maps of average $C Q_{\text {eff }}$ to compare the different spatial patterns and runoff values. The $D 8$ algorithm generates the same maps with and without adding the threshold value. The coefficients of runoff production in the catchment and runoff production to the lake, from now on termed runon, were calculated for the whole of the Estaña Lakes catchment and the two selected catchments (Table 1). The runoff coefficients (CQC) ranged from 19.4\% (DInf algorithm) to $34.9 \%$ (BDR with threshold value) in the EA Lake catchment and from $17.3 \%(D 8)$ to $21.1 \%$ $(B D R)$ in the EGA Lake catchment. The breakup of flow paths with some of the algorithms (e.g. $D 8$ ) and the continuity with others (e.g. $B D R$ ) modifies the connectivity of the cells between them and explains the variation in the estimated CQC. The runon coefficients (CQC-on) were very low and remained between $0.2 \%$ and $0.3 \%$ in both lakes. These predicted coefficients are consistent with those calculated by Pérez-Bielsa [2013] after performing the water balance of the Estaña 
Lakes catchment using data on the local aquifer, soil properties and climatic parameters. This author obtained an average annual CQC of $32 \%$ and below $1 \%$ of CQC-on.

A quality analysis was done, comparing the 15 spatial patterns of runoff with field measurements and observations (Fig. 4) [López-Vicente et al., 2009a]. The location and dimensions of the 16 gully systems, ephemeral gullies and flat areas were used. The Rho8, DInf, $M F D$ with threshold values for linear flow, MFD-Th., and TMFD algorithms gave better predictions of areas of concentrated runoff in the gullies and the main rills and of the spread of runoff in the flat areas. The other 11 spatial patterns did not provide a satisfactory match with the geomorphic features of the Estaña Lakes catchment. Analyses comparing predicted runoff depth with water level and volume variation values in the two lakes were performed with the four selected FAAs.

\subsection{Runoff contribution vs. water level of lakes}

In the EA Lake catchment the average CQC calculated for the 69-month test period were $25.0 \%, 18.0 \%, 25.7 \%$ and $24.8 \%$ for the Rho8, DInf, MFD-Th. and TMFD algorithms, respectively (Fig. 5.a) and the CQC-on were $0.18 \%, 0.19 \%, 0.14 \%$ and $0.15 \%$, respectively (Fig. 5.b). The Pearson's coefficients of correlation between the monthly values of $E R$ and $C Q_{\text {eff }}$ for the four FAAs were $0.988,0.988,0.987$ and 0.990 , respectively. The average coefficient of correlation between ER and runon for the four FAAs was 0.933. In the EGA Lake catchment the average CQC were lower than in the EA Lake catchment, with values of $15.3 \%, 16.6 \%, 15.9 \%$ and $15.8 \%$ for the Rho8, DInf, MFD-Th. and TMFD algorithms, respectively (Fig. 5.c). However, the CQC-on were higher than in the EA Lake with values of $0.26 \%, 0.23 \%, 0.22 \%$ and $0.23 \%$, respectively (Fig. 5.d). Pearson's coefficients of correlation between $E R$ and $C Q_{\text {eff }}$ ranged between 0.984 and 0.989 but the correlation between the $E R$ and the runon was higher than in the EA Lake, with an average value of 0.991 . These results highlight the complexity and non- 
linearity of the processes involved in runoff generation that describe a slightly different pattern of runoff in the two catchments, explained by their different sizes, the percentages of each soil type and the different distribution of steep and gentle slope areas. Predicted CQC agree with measured coefficients in other Spanish mountainous catchments (between 23-35\%) [Palleiro et al., 2014] and also the observed spatial variability of CQC agree with the variability found in other Spanish karst landscapes [Li et al., 2011]. The very low values of CQC-on are explained by the small size of the area contributing to the lakes, karst processes that favor the development of flat bottom valleys and uvalas which inhibit the existence of permanent streams, the overall scarcity of precipitation during the analyzed period, the high infiltration rates of the soils and by the humanmade infrastructures that add a significant number of landscape linear elements decreasing runoff connectivity. The spatial complexity, patterns and values, of simulated runoff in the Estaña Lakes catchment are in agreement with the findings of McGlynn et al. [2004] regarding different runoff responses, velocity and coefficients, at headwaters and hillslopes in a similar size catchment, at storm event scale.

The correlation between the values of predicted runon depth $\left(C Q_{\text {eff }}, \mathrm{mm}\right)$ and the values of lake level variations (m) in the EA and EGA Lakes was carried out for the 69-month test period (Table 2). The Pearson correlation coefficients obtained for the whole period were below 0.5 in all cases. We assume that there is higher degree of error in this correlation because we ran the $D R 2-2013^{\odot}$ tool with rainfall data from the Canelles weather station, that is not located within the study area and thus some simulated runoff events appeared with no change or little change in water levels (see Figure 3.c). When the test period was split into the wet season (from October till March) and dry season (from April till September) correlations clearly improved, resulting in many values above 0.5 . These results reveal that the magnitude of the processes differs during the wet and dry seasons, controlling the water volume in both lakes and the stored water depth in the soil profile and the runoff yield in hillslopes. 
In order to analyze the different response times of the two lakes to the groundwater and runoff supplies, we also calculated the correlation between the predicted values of runoff in a month $m$ and the variations of the water level in the next month, $m+1$ (Table 2). The best coefficients of correlation in the EGA Lake were obtained with a response time $m+1$ for the four selected FAAs and considering the 69 months, the dry and the wet periods. However, in the EA Lake the best correlations were found with the short response time $m$ in the dry period and the 69-month test period, and with the response time $m+1$ for the wet period except for the predicted runon values with the Rho8 algorithm. We hypothesized that the different response times could be explained by the spatial location of each lake and catchment lake in relation to the outcrops of limestones, clays and evaporates that have different water infiltration values, the size of the contributing areas, and the values of aquifer transmissivity. The EGA Lake is influenced to a greater extent by evaporite-clay materials, which could explain the slower response of the water level to recharge than that observed in the EA Lake. The best correlations in the EA Lake where obtained with the Rho8 algorithm for the wet season, and with the DInf and TMFD algorithms for the dry season. In the EGA Lake, the MFD-Th. and TMFD algorithms perform best for the dry season and the TMFD algorithm for the wet season. We hypothesized that the differences observed between the most suitable FAAs in each season can be explained by the temporal differences in runoff production and thus in the spatial patterns of overland flow in each season due to changes in the values of rainfall intensity and depth.

\subsection{Estimation of the water volume of the EGA Lake with different FAAs}

The predictive power of the $D R 2-2013^{\odot}$ tool to estimate the water volume of the EGA Lake was assessed at monthly scale, $\operatorname{VLpred}_{m}\left(\mathrm{~m}^{3}\right)$, as well as assessing its ability to better discriminate the most appropriate FAA. We used our own basic water balance equation that considers the main inputs and outputs to the lake. Inputs are the measured volume of the lake in the previous 
month, VLmeas $\left(\mathrm{m}^{3}\right)$, the effective rainfall that directly reaches the lake surface, $E R_{m}\left(\mathrm{~m}^{3}\right)$, the volume of water coming from the aquifer, $Q_{i n}\left(\mathrm{~m}^{3}\right)$, and the predicted volume of runoff that reaches the lake shores, $C Q_{\text {eff- } m}\left(\mathrm{~m}^{3}\right)$. The total volume of water leaving the lake is the monthly evaporation, $E v_{m}\left(\mathrm{~m}^{3}\right)$, and the exit from the lake to the aquifer, $Q_{\text {out }}\left(\mathrm{m}^{3}\right)$. We used constant values of $Q_{i n}$ and $Q_{o u t}$, without temporal variations, in order to analyze the runoff contribution easily with lower mathematical uncertainty:

$$
\text { VLpred }_{m}=\text { VLmeas }_{m-1}+E R_{m}+Q_{\text {in }}+C Q_{e f-m}-E v_{m}-Q_{\text {out }}
$$

Predicted and measured values were analyzed, obtaining very high values of the Pearson correlation coefficients with the four selected FAAs, above 0.98664 (Table 3). Given that runoff production and variations in the volume of the lakes are non-normal variables, the Nash-Sutcliffe model efficiency coefficient was also calculated, obtaining values ca. 0.9704 (Table 3) that shows the high accuracy of the model. The highest coefficients were obtained with the MFD-Th. algorithm followed by the TMFD algorithm highlighting that the multiple flow approaches performed the actual patterns and values of runoff better than the single flow direction algorithms. Pilesjö and Hasan [2014] also obtained the most consistent outcomes to track flow paths with the TMFD algorithm compared to other approaches. Finally, the prediction capability of the model to assess predominant processes in the rise and fall of the water levels was analyzed (Fig. 6). Although correlation was not statistically significant, guide threshold values were estimated. In the EA Lake, the threshold value of runon depth that leads to the drop in the water level was $3600 \mathrm{~mm}$ per year and the threshold for a predominant rise was $4200 \mathrm{~mm}$ per year. In the case of the EGA Lake, the threshold values were 4000 and $6000 \mathrm{~mm}$ per year of runon depth, respectively. This prediction capability will be useful to evaluate in advance the consequences of different climatic and land management scenarios that could further the sustainable development of the Estaña Lakes system. 


\subsection{Future research}

Since differences in model efficiency between the multiple and the single flow direction algorithms were very slight, further research needs to focus on analyzing runoff production at the different landscape units (headwaters, hillslopes and lowlands) in order to refine assessment of the best FAA.

The next stages of the project will focus on: (1) using a LIDAR (LIght Detection And Ranging) derived DEM at high spatial resolution to test the accuracy of the predictions with the different FAAs; and (2) further research related to the influence of the water table location in the soils surrounding the lakes on infiltration rates and thus runoff yield.

\section{Conclusions}

The DR2-2013 ${ }^{\odot}$ SAGA $v 1.0$ software allows simulation of runoff with 8 flow accumulation algorithms and under 15 spatial patterns. The new module generates and operates a large number of maps in a short period of time and thus is a powerful tool in hydrological studies at hillslope scale. This model is also suitable for areas where data is limited due to a moderate number of inputs.

The predicted runoff coefficients are consistent with those calculated after performing the water balance of the Estaña Lakes catchment using data on the local aquifer, soil properties and climatic parameters supporting the ability of the DR2-2013 model to predict accurate runoff values. The breakup of flow paths with some algorithms and the continuity with others modifies the connectivity of the cells between them and explains the variation of the estimated runoff coefficients. The single direction Rho8 and DInf algorithms, the multiple direction MFD with threshold value for linear flow, MFD-Th., and the TMFD algorithms best described the runoff concentrated into rills, ephemeral and permanent gullies and ditches, and the spread of runoff on the flat areas. 
The correlation between the values of predicted runon depth with the four selected FAAs and the values of lake level variations was weak when the whole period was considered and higher when the 69 months were split into the wet (October - March) and dry (April - September) seasons. Runoff simulation also reflected the different response time of the water levels of the two lakes to their corresponding runoff contribution. The location of each lake in relation to the outcrops of limestone and clay and their upslope area mainly explain this different behavior.

The prediction capability of the model was tested as a part of the water balance of the EGA Lake and the highest coefficients of both the Pearson correlation and Nash-Sutcliffe model efficiency were obtained with the two multiple flow algorithms selected, although the differences in the efficiency of the model were very slight between the multiple and the single flow direction approaches. Finally, the $D R 2-2013^{\odot}$ tool helped to predict the rise and fall of the water level lakes under different threshold values of runoff yield. The results of this study can help lake stakeholders to manage overland flow and have broader implications for understanding the simulation of flow accumulation and paths, and hydrologic connectivity in catchments.

\section{Acknowledgements}

This research was funded by the Projects: i) "Mitigation of siltation of the Estaña Lakes Wetlands (Huesca, Spain) under different scenarios of climate change: soil and water trapping effectiveness of the "green areas" of the new CAP (2012 GA LC 034)" of the Regional Government of Aragón (Spain) and Obra Social "la Caixa"; ii) "Erosion and redistribution of soils and nutrients in Mediterranean agroecosystems: radioisotopic tracers of sources and sinks and modeling of scenarios (EROMED EROMED; CGL2011-25486/BTE)" of the Spanish Ministry of Economy and Competitiveness and iii) "Funcionamiento hidrológico de humedales relacionados con las aguas subterráneas en la cuenca del Ebro (2007-2010)" of the Spanish Geological Survey (IGME). We also thank the IPE-CSIC center for providing data for the development of the EGA Lake bathymetry. The Ebro Water Authorities (CHE) and the "Instituto Aragonés de Gestión Ambiental" (INAGA) are greatly acknowledged for the permits and assistance provided. 


\section{References}

Bauer, J., H. Rohdenburg, and H.-R. Bork (1985), "Ein Digitales Reliefmodell als Vorraussetzung fuer ein deterministisches Modell der Wasser- und Stoff-Fluesse”, in: Landschaftsgenese und Landschaftsoekologie, H.10, Parameteraufbereitung fuer deterministische Gebiets-Wassermodelle, Grundlagenarbeiten zu Analyse von Agrar-Oekosystemen (Eds.: Bork H-R and Rohdenburg H), 1-15.

Borselli, L., P. Cassi, and D. Torri (2008), Prolegomena to sediment and flow connectivity in the landscape: A GIS and field numerical assessment, Catena 75(3), 268-277.

Brown, T.N., C.A. Johnston, and K.R. Cahow (2003), Lateral flow routing into a wetland: field and model perspectives, Geomorphology 53(1-2), 11-23.

Choi, Y (2012), A new algorithm to calculate weighted flow-accumulation from a DEM by considering surface and underground stormwater infrastructure, Environmental Modelling \& Software 30, 81-91.

Clarke, K.C., and S.J. Lee (2007), Spatial resolution and algorithm choice as modifiers of downslope flow computed from digital elevation models, Cartography and Geographic Information Science 34(3), 215-230.

Costa-Cabral, M., and S.J. Burges (1994), Digital Elevation Model Networks (DEMON): a model of flow over hillslopes for computation of contributing and dispersal areas, Water Resources Research 30, 1681-1692.

Custodio, E., and M.R. Llamas (1983), Hidrología subterránea, Ediciones Omega 2. Vol: 1-2350. Barcelona.

Endreny, T.A., and E.F. Wood (2003), Maximizing spatial congruence of observed and DEM-delineated overland flow networks, International Journal of Geographical Information Science 17(7), 699-713.

Eriksson, E., and V. Khunakasem (1969), Chloride concentration in ground water, recharge rate and rate of deposition of chloride in the Israel Coastal Plain, Journal of Hydrology 7(2), 178-197.

Fairfield, J., and P. Leymarie (1991), Drainage networks from grid digital elevation models, Water Resources Research 27, 709-717.

Freeman, G.T. (1991), Calculating catchment area with divergent flow based on a regular grid, Computers and Geosciences, 17(3), 413-422.

Gallant, J.C., and J.P. Wilson (1996), TAPES-G: A grid-based terrain analysis program for the environmental sciences, Computers and Geosciences 22(7), 713-722.

Gilley, J.E., and S.C. Finkner (1991), Hydraulic Roughness Coefficients as Affected by Random Roughness, Transactions of the ASAE 34(3), 897-903.

Halwatura, D. and M.M.M. Najim (2013), Application of the HEC-HMS model for runoff simulation in a tropical catchment, Environmental Modelling \& Software 46, 155-162. 
Huang, J.-C., S.-J. Kao, M.-L. Hsu, and Y.-A. Liu (2007), Influence of specific contributing area algorithms on slope failure prediction in landslide modeling, Natural Hazards and Earth System Science 7(6), 781-792.

Jensen, J.R. (1996), “Introductory Digital Image Processing: A Remote Sensing Perspective”, in: N.J. Englewood Cliffs, Prentice Hall.

Lea, N.L. (1992), “An aspect driven kinematic routing algorithm” in: Parsons, A.J., and A.D. Abrahams (Eds.), Overland Flow: hydraulics and erosion mechanics, London, 147-175.

Li, X.-Y., S. Contreras, Solé-Benet, A., Cantón Y., Domingo F., Lázaro R., Lin H., Van Wesemael B., and J. Puigdefábregas (2011), Controls of infiltration-runoff processes in Mediterranean karst rangelands in SE Spain, Catena 86(2), 98-109.

Liu, H., J. Kiesel, G. Hörmann, and N. Fohrer (2011), Effects of DEM horizontal resolution and methods on calculating the slope length factor in gently rolling landscapes, Catena 87(3), 368-375.

López-Montero, T., M. López-Vicente, and A. Navas (2013), Modelling surface hydrology with DR2-SAGA 1.0: development of a user-friendly interface for hillslope water balance assessments, Geophysical Research Abstracts 15, EGU2013-1437-2.

López-Vicente, M., and A. Navas (2010), Routing runoff and soil particles in a distributed model with GIS: Implications for soil protection in mountain agricultural landscapes, Land Degradation and Development 21(2), 100-109.

López-Vicente, M., and A. Navas (2012), A new distributed rainfall-runoff model (DR2) based on soil saturation and runoff cumulative processes, Agricultural Water Management 104, 128-141.

López-Vicente, M., A. Navas, L. Gaspar, and J. Machín (2013), Advanced modelling of runoff and soil redistribution for agricultural systems: The SERT model, Agricultural Water Management 125, 1-12.

López-Vicente, M., A. Navas, L. Gaspar, and J. Machín (2014), Impact of the new Common Agricultural Policy of the EU on the runoff production and soil moisture content in a Mediterranean agricultural system, Environmental Earth Sciences 71(10), 4281-4296.

López-Vicente, M, A. Navas, and J. Machín (2009a), Geomorphic mapping in endorheic catchments in the Spanish Pyrenees: an integrated GIS analysis of topographic-karstic features, Geomorphology 111(1-2), 38-47.

López-Vicente, M., A. Navas, and J. Machín (2009b), Effect of physiographic conditions on the spatial variation of seasonal topsoil moisture in Mediterranean soils, Australian Journal of Soil Research, 47(5), 498-507.

Macías, I.G. (2013), “Las lagunas de Estaña se secan al denegar el Inaga una autorización”, in: Heraldo de Aragón (Newspaper), June 2, 2013, pp 8. 
McGlynn, B.L., McDonnell, J.J., Seibert, J., and C. Kendall (2004), Scale effects on headwater catchment runoff timing, flow sources, and groundwater-streamflow relations, Water Resources Research 40(7), W075041W0750414.

Morellón, M., B. Valero-Garcés, P. González-Sampériz, T. Vegas-Vilarrúbia, E. Rubio, M. Rieradevall, A. DelgadoHuertas, P. Mata, O. Romero, D.R. Engstrom, M. López-Vicente, A. Navas, and J. Soto (2011), Climate changes and human activities recorded in the sediments of Lake Estanya (NE Spain) during the Medieval Warm Period and Little Ice Age, Journal of Paleolimnology 46(3), 423-452.

O'Callaghan, J.F., and D.M. Mark (1984), The extraction of drainage networks from digital elevation data, Computer Vision, Graphics, and Image Processing 28, 323-344.

Palleiro, L., M.L. Rodríguez-Blanco, M.M. Taboada-Castro and M.T. Taboada-Castro (2014), Hydrological response of a humid agroforestry catchment at different time scales, Hydrological Processes 28(4), 1677-1688.

Pérez-Bielsa, C. (2013), "Funcionamiento hidrogeológico de un humedal hipogénico de origen kárstico en las Sierras Marginales Pirenaicas: Las Lagunas de Estaña (Huesca)", Doctoral Thesis, Instituto Geológico y Minero de España - Unidad de Zaragoza, Universidad Complutense de Madrid, Departamento de Geodinámica, 420 pp.

Pérez-Bielsa, C., and L.J. Lambán (2009), Primeros resultados obtenidos sobre el funcionamiento hidrogeológico de la Lagunas de Estaña y su relación con el acuífero de Estopiñán (Huesca, España), Boletín Geológico y Minero 120(3), 443-458.

Pérez-Bielsa, C., L.J. Lambán, J.L. Plata, F.M. Rubio, and R. Soto (2012), Characterization of a karstic aquifer using magnetic resonance sounding and electrical resistivity tomography: a casa-study of Estaña Lakes (northern Spain), Hydrogeology Journal 20(6), 1045-1059.

Pérez-Bielsa, C., J. Ramajo Cordero, and L.J. Lambán Jiménez (2008), Marco geológico e hidrogeológico del entorno de las Lagunas de Estaña (Huesca, España), GEO-TEMAS 10, 252.

Pilesjö, P., and A. Hasan (2014), A Triangular Form-based Multiple Flow Algorithm to Estimate Overland Flow Distribution and Accumulation on a Digital Elevation Model, Transactions in GIS 18(1), 108-124.

Quinn, P.F., K.J. Beven, P. Chevallier, and O. Planchon (1991), The prediction of hillslope flow paths for distributed hydrological modelling using digital terrain models, Hydrological Processes, 5, 59-79.

Rampi, L.P., J.F. Knight, and C.F. Lenhart (2014), Comparison of flow direction algorithms in the application of the cti for mapping wetlands in Minnesota, Wetlands 34(3), 513-525.

Renard, K.G., G.R. Foster, G.A. Weesies, and J.P. Porter (1991), RUSLE - Revised universal soil loss equation, Journal of Soil and Water Conservation 46(1), 30-33. 
Schäuble, H., O. Marinoni, and M. Hinderer (2008), A GIS-based method to calculate flow accumulation by considering dams and their specific operation time, Computers and Geosciences, 34(6), 635-646.

Seibert, J., and B.L. McGlynn (2007), A new triangular multiple flow direction algorithm for computing upslope areas from gridded digital elevation models, Water Resources Research 43(4), art. no. W04501.

Tarboton, D.G. (1997), A new method for the determination of flow directions and upslope areas in grid digital elevation models, Water Resources Research 33(2), 309-319.

Tarboton, D.G., and M.E. Baker (2008), "Towards an Algebra for Terrain-Based Flow Analysis" in Representing, Modeling and Visualizing the Natural Environment: Innovations in GIS 13, Edited by N. J. Mount, G. L. Harvey, P. Aplin and G. Priestnall, CRC Press, Florida.

Tesfa, T.K., D.G. Tarboton, D.W. Watson, K.A.T. Schreuders, M.E. Baker, and R.M. Wallace (2011), Extraction of hydrological proximity measures from DEMs using parallel processing, Environmental Modelling and Software 26(12), 1696-1709.

White, M.J., D.E. Storm, P.R. Busteed, M.D. Smolen, H. Zhang, and G.A. Fox (2010), A quantitative phosphorus loss assessment tool for agricultural fields, Environmental Modelling \& Software 25(10), 155-162.

Wolock, D.M., and G.J. McCabe Jr (1995), Comparison of single and multiple flow direction algorithms for computing topographic parameters in TOPMODEL, Water Resources Research 31(5), 1315-1324. 
Figure 1. Flow accumulation estimated from different algorithms (modified from Schäuble et al., 2008; Tesfa et al., 2011; and Pilesjö and Hasan, 2014). D8: Deterministic eight-node algorithm; and D $\infty$ : Deterministic Infinity algorithm.

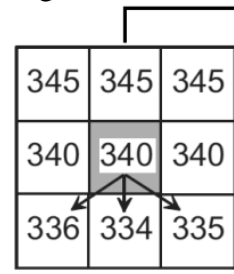

Elevations

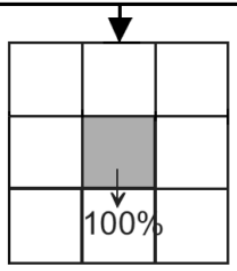

Single-flow

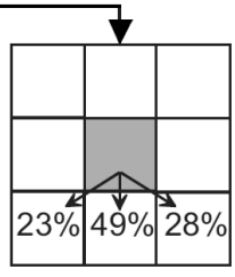

Multiple-flow
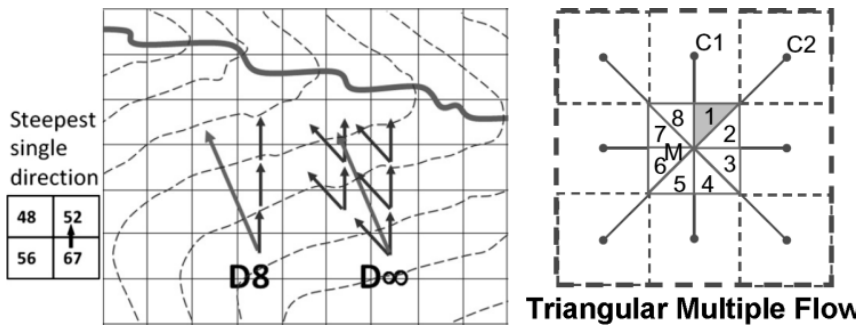

Triangular Multiple Flow

Figure 2. (a) Geographic location of the study area within the Ebro river basin (NE Spain), (b) map of the Estaña Lakes Catchment with the boundaries between the different sub-catchments and (c) picture showing the main lakes at the bottom of the catchment.
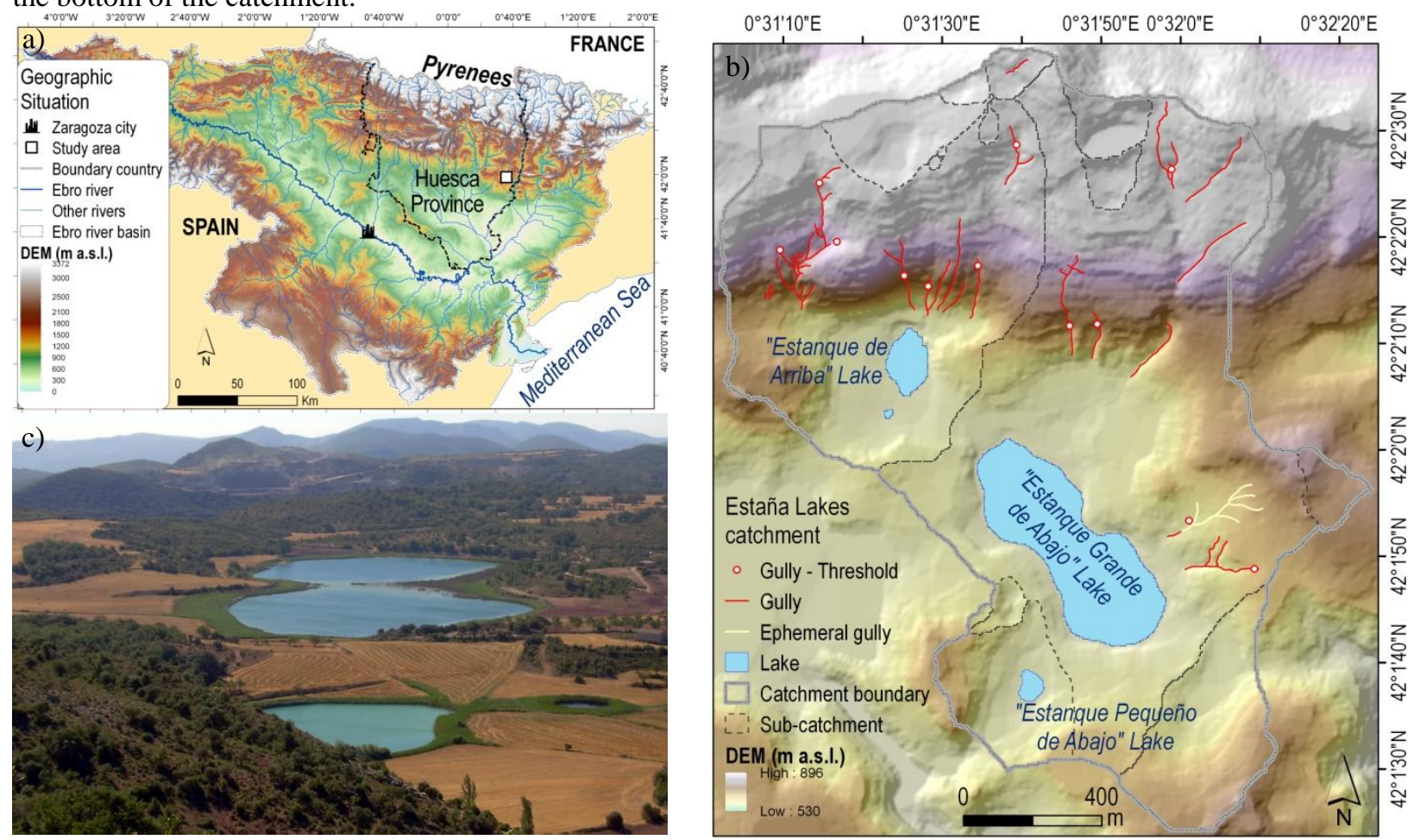
Figure 3. (a) Monthly values of rainfall depth $(R, \mathrm{~mm})$ and average of maximum rainfall intensity $\left(I_{30}, \mathrm{~mm} / \mathrm{h}\right)$ measured at the Canelles weather station and of potential evapotranspiration at the Barbastro weather station, (b) pictures of the equipment installed to measure the water level of the EA and EGA Lakes, and (c) daily values of rainfall depth (Estaña weather station) and of the water level of the EA and EGA Lakes.

a)

$$
\begin{aligned}
& 220 \\
& 200
\end{aligned}
$$

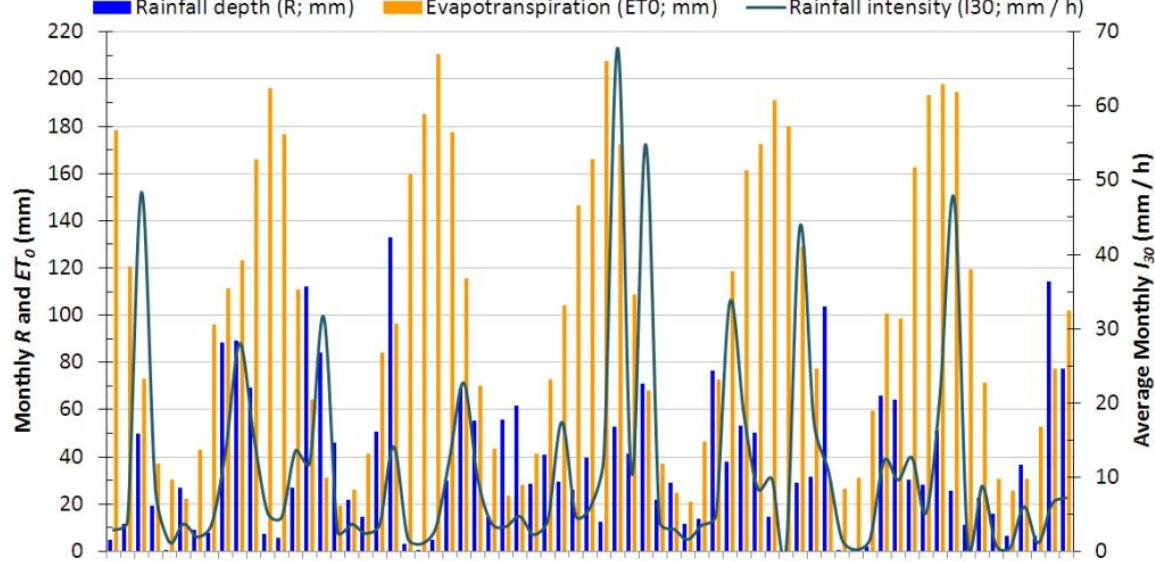

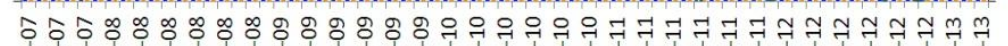

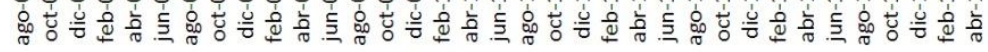

c) Month and year
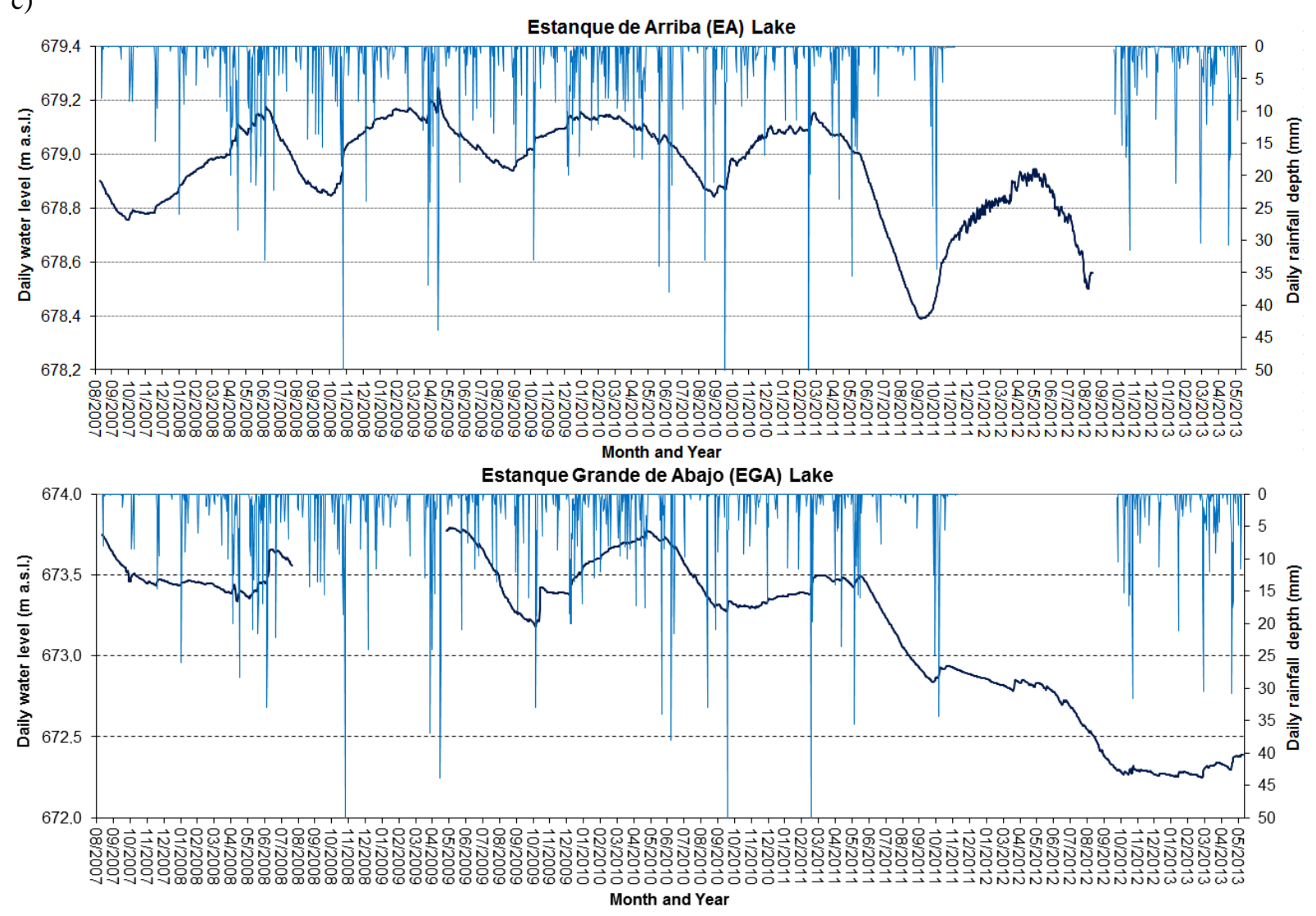

b)
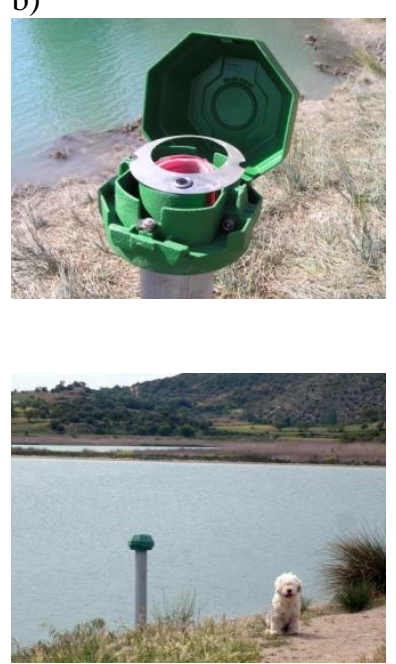
Figure 4. Control areas selected to perform the visual quality analysis of the runoff production with the different FAAs in (a) steep slopes near the EA Lake, (b) gullies in moderate slopes and flat areas surrounding the EGA Lake, and (c) in the ephemeral gully systems in cultivated soils close to the EGA Lake. DInf: Deterministic Infinity; Rho8-Th.: Quasi-random eight-node with threshold value for linear flow; MFD: Multiple Flow Direction; TMFD: Triangular Multiple Flow Direction.
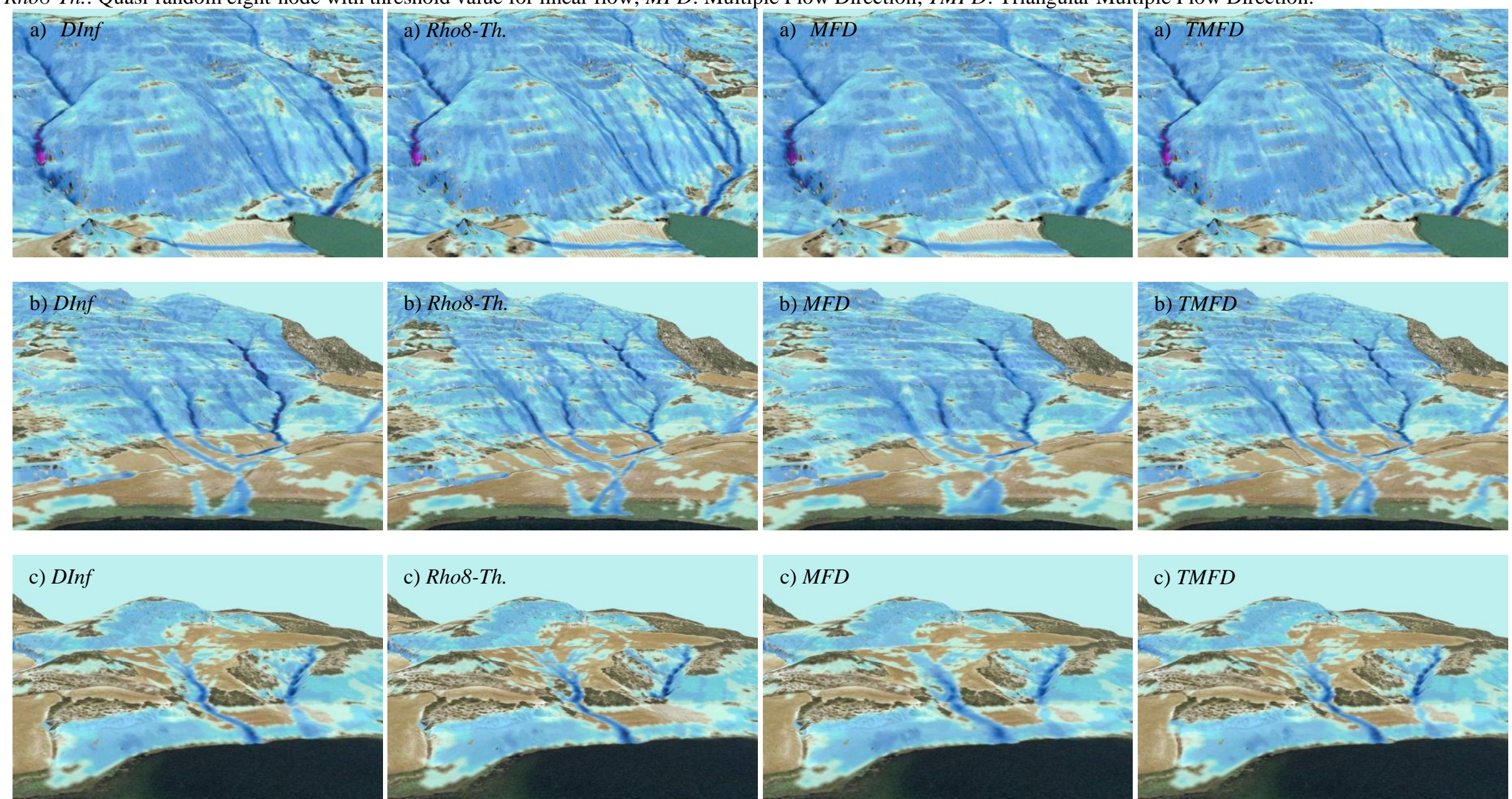

c) $M F D$

c) $T M F D$
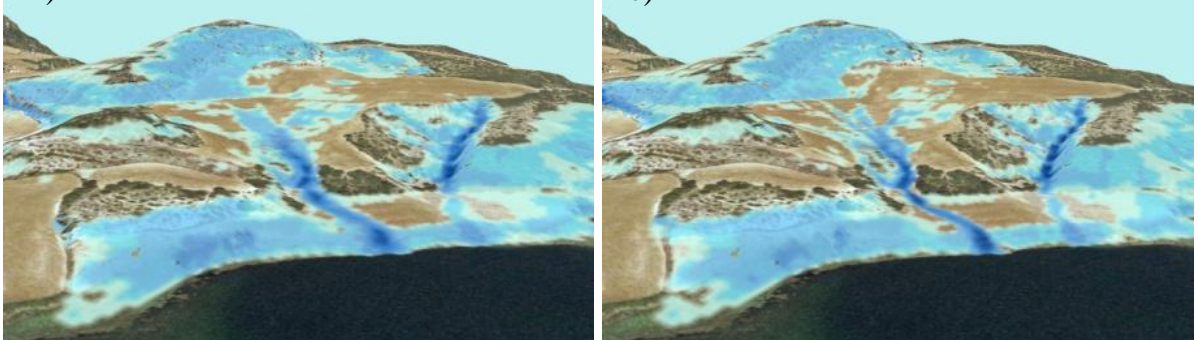
Figure 5. Runoff and runon coefficients calculated with the four selected flow accumulation algorithms at the EA and EGA Lakes catchments.
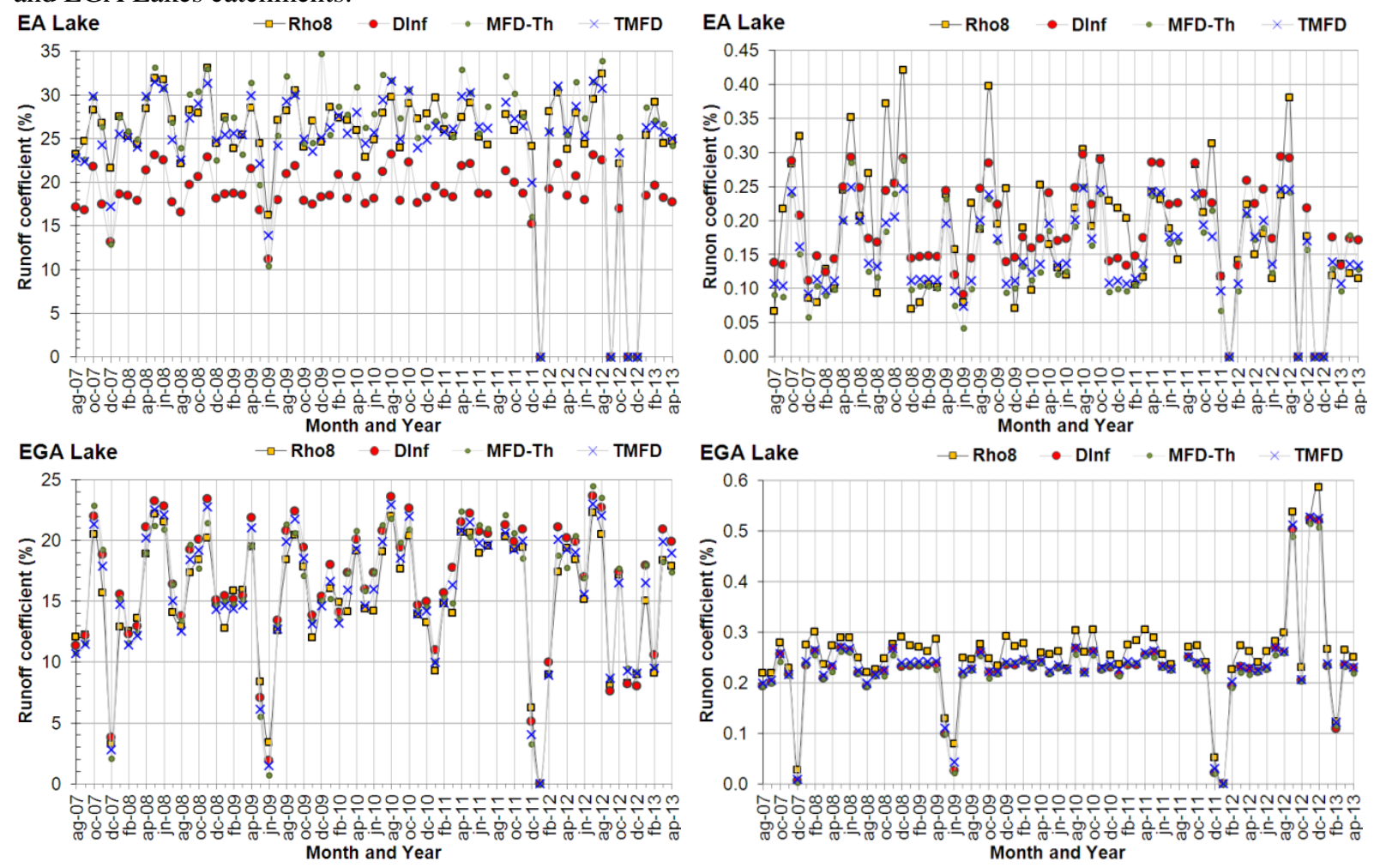

Figure 6. Correlation of predicted runon values with the four selected FAAs and variation of the water level of the EA and EGA Lakes. Identification of the runon threshold values to predict predominant processes of drop and rise of the water level of the lakes.
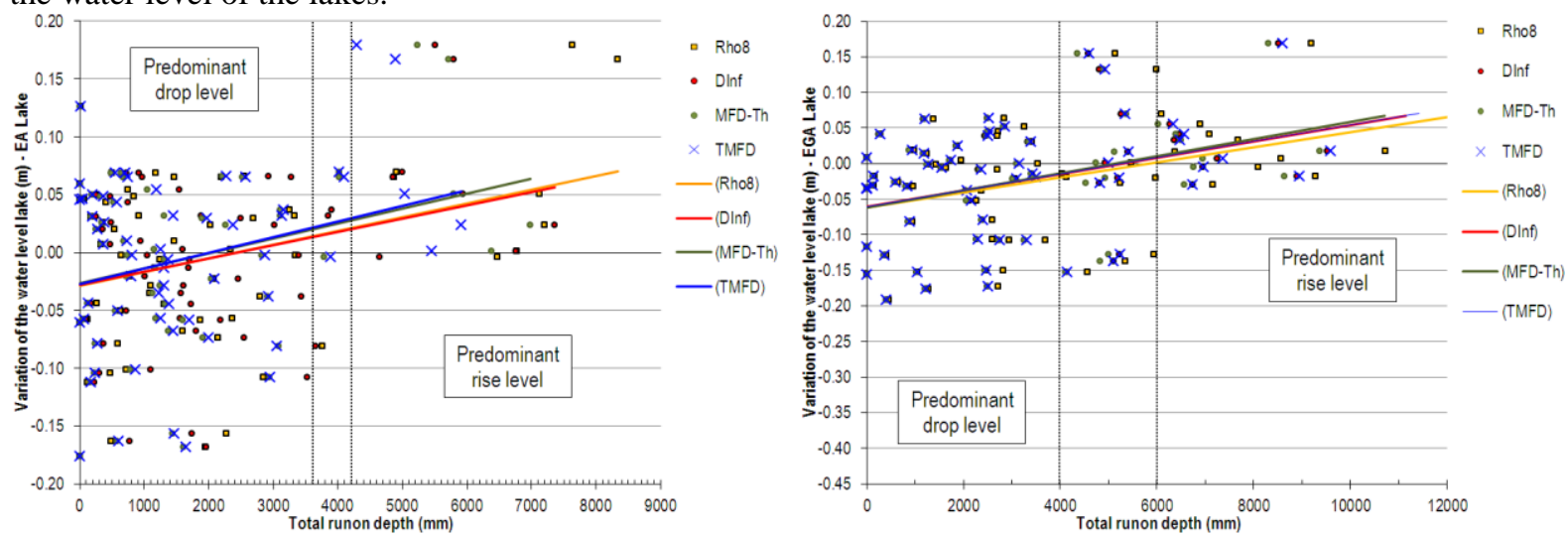
Table 1 Average yearly runoff depth and runoff and runon coefficients calculated with the eight overland flow accumulation algorithms for the whole Estaña Lakes catchment and the EA and EGA Lakes sub-catchments for a period of 15 years (1997-2011).

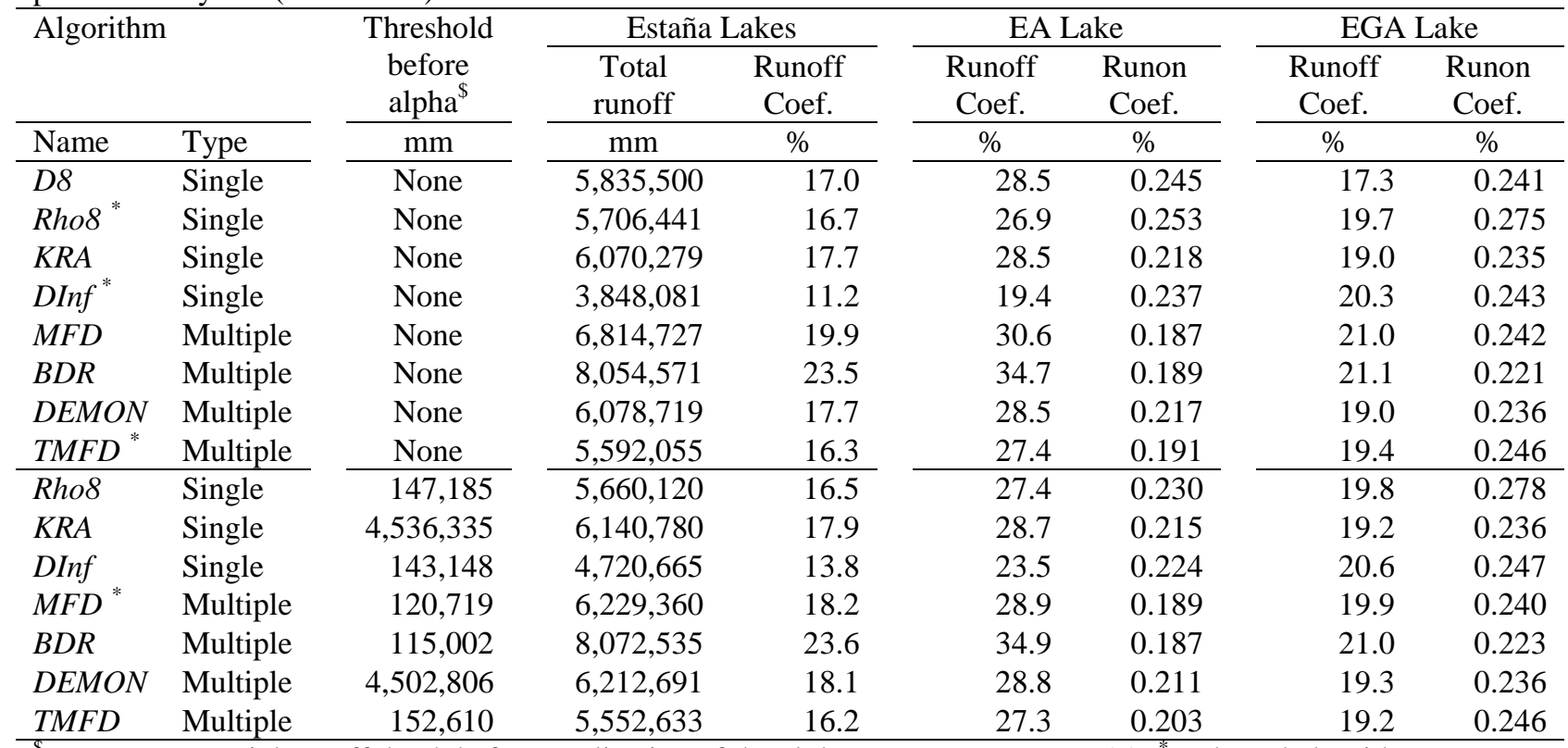

\$: average potential runoff depth before application of the alpha parameter, see Eq. (7); ${ }^{*}$ : selected algorithm.

Table 2 Pearson correlation coefficients between the values of predicted runon depth with the DR2-2013 ${ }^{\odot} S A G A$ $v 1.0$ model $\left(C Q_{e f f}, \mathrm{~mm}\right)$ and the values of lake level variations $(\mathrm{m})$ in the EA and EGA Lakes with the four selected FAAs; $m$ : month. Bold face numbers are significant at the $95 \%$ confidence level.

\begin{tabular}{|c|c|c|c|c|c|}
\hline \multirow[t]{2}{*}{ Lake } & \multirow[t]{2}{*}{ Algorithm } & \multirow{2}{*}{$\begin{array}{c}\text { Lake level variation } \\
\text { Response time }\end{array}$} & \multicolumn{3}{|c|}{ Temporal period } \\
\hline & & & All period & Wet seasons & Dry seasons \\
\hline \multirow[t]{8}{*}{ EA } & Rho8 & $m$ & 0.426 & 0.668 & 0.545 \\
\hline & & $m+1$ & 0.317 & 0.444 & 0.413 \\
\hline & DInf & $m$ & 0.328 & 0.399 & 0.604 \\
\hline & & $m+1$ & 0.253 & 0.568 & 0.318 \\
\hline & $M F D-T h$. & $m$ & 0.328 & 0.420 & 0.586 \\
\hline & & $m+1$ & 0.252 & 0.553 & 0.315 \\
\hline & $T M F D$ & $m$ & 0.326 & 0.404 & 0.595 \\
\hline & & $m+1$ & 0.249 & 0.542 & 0.323 \\
\hline \multirow[t]{8}{*}{ EGA } & Rho8 & $m$ & 0.233 & 0.227 & 0.334 \\
\hline & & $m+1$ & 0.363 & 0.477 & 0.688 \\
\hline & DInf & $m$ & 0.222 & 0.227 & 0.322 \\
\hline & & $m+1$ & 0.353 & 0.477 & 0.693 \\
\hline & $M F D-T h$. & $m$ & 0.237 & 0.246 & 0.330 \\
\hline & & $m+1$ & 0.358 & 0.474 & 0.698 \\
\hline & TMFD & $m$ & 0.228 & 0.315 & 0.328 \\
\hline & & $m+1$ & 0.357 & 0.478 & 0.695 \\
\hline
\end{tabular}

Table 3 Pearson correlation coefficients and Nash-Sutcliffe model efficiency coefficients between the predicted volumes of water for the EGA lake at each month, $\operatorname{VLpred}_{m}\left(\mathrm{~m}^{3}\right)$, with the DR2-2013 ${ }^{\odot} S A G A v 1.0$ model and the four selected FAAs and the measured volumes of water, VLmeas ${ }_{m}\left(\mathrm{~m}^{3}\right)$ (more details in Eq.(11)). Bold face numbers are significant at the $95 \%$ confidence level.

\begin{tabular}{|c|c|c|c|}
\hline \multirow{5}{*}{$\frac{\text { Lake }}{\text { EGA }}$} & Algorithm & Pearson coefficients & Nash-Sutcliffe coefficients \\
\hline & Rho8 & 0.9866440 & 0.97039570 \\
\hline & $D \operatorname{Inf}$ & 0.9866470 & 0.97039425 \\
\hline & $M F D-T h$ & 0.9866483 & 0.97039687 \\
\hline & $T M F D$ & 0.9866473 & 0.97039571 \\
\hline
\end{tabular}

